OPEN ACCESS

Edited by:

María M. Malagón,

Instituto Maimónides de

Investigación Biomédica

de Córdoba, Spain

Reviewed by:

Luis Miguel Garcia-Segura, Consejo Superior de Investigaciones

Cientificas (CSIC), Spain

Julie A. Chowen,

Hospital Infantil Universitario Niño

Jesús, Spain

*Correspondence:

Olfa Masmoudi-Kouki

olfa.masmoudi@fst.utm.tn

Specialty section:

This article was submitted to Neuroendocrine Science,

a section of the journal

Frontiers in Endocrinology

Received: 19 January 2017

Accepted: 23 March 2017

Published: 10 April 2017

Citation:

Amri F, Ghouili I, Tonon M-C, Amri M and Masmoudi-Kouki O (2017) Hemoglobin-Improved Protection in Cultured Cerebral Cortical Astroglial Cells: Inhibition of Oxidative Stress and Caspase Activation.

Front. Endocrinol. 8:67. doi: 10.3389/fendo.2017.00067

\section{Hemoglobin-Improved Protection in Cultured Cerebral Cortical Astroglial Cells: Inhibition of Oxidative Stress and Caspase Activation}

\author{
Fatma Amri', Ikram Ghouili', Marie-Christine Tonon ${ }^{2}$, Mohamed Amri ${ }^{1}$ and \\ Olfa Masmoudi-Kouki ${ }^{1 *}$ \\ 'University of Tunis El Manar, Faculty of Sciences of Tunis, UR/11ESO9 Laboratory of Functional Neurophysiology and \\ Pathology, Tunis, Tunisia, ${ }^{2}$ INSERM U1239, Laboratory of Neuronal and Neuroendocrine Communication and \\ Differentiation, Institute for Research and Innovation in Biomedicine (IRIB), University of Rouen Normandie, \\ Mont-Saint-Aignan, France
}

Oxidative stress plays a major role in triggering astroglial cell death in diverse neuropathological conditions such as ischemia and neurodegenerative diseases. Numerous studies indicate that hemoglobin $(\mathrm{Hb})$ is expressed in both resting and reactive glia cells, but nothing is known regarding a possible role of $\mathrm{Hb}$ on astroglial cell survival. Thus, the purpose of the present study was to investigate the potential glioprotective effect of $\mathrm{Hb}$ on hydrogen peroxide $\left(\mathrm{H}_{2} \mathrm{O}_{2}\right)$-induced oxidative stress and apoptosis in cultured rat astrocytes. Our study demonstrates that administration of graded concentrations of $\mathrm{Hb}\left(10^{-12}\right.$ to $\left.10^{-6} \mathrm{M}\right)$ to $\mathrm{H}_{2} \mathrm{O}_{2}$-treated astrocytes reduces cell death in a concentrationdependent manner. $\mathrm{H}_{2} \mathrm{O}_{2}$ treatment induces the accumulation of reactive oxygen species (ROS) and nitric oxide (NO), a drop of the mitochondrial membrane potential, and a stimulation of caspase-3/7 activity. Exposure of $\mathrm{H}_{2} \mathrm{O}_{2}$-treated cells to $\mathrm{Hb}$ was accompanied by marked attenuations of ROS and NO surproductions, mitochondrial membrane potential reduction, and caspase-3/7 activity increase. The protective action of $\mathrm{Hb}$ was blocked by the protein kinase $\mathrm{A}(\mathrm{PKA})$ inhibitor $\mathrm{H} 89$, the protein kinase $\mathrm{C}$ (PKC) inhibitor chelerythrine, and the mitogen-activated protein (MAP)-kinase kinase (MEK) inhibitor U0126. Taken together, these data demonstrate for the first time that $\mathrm{Hb}$ is a glioprotective factor that protects astrocytes from apoptosis induced by oxidative stress and suggest that $\mathrm{Hb}$ may confer neuroprotection in neurodegenerative diseases. The anti-apoptotic activity of $\mathrm{Hb}$ on astrocytes is mediated through the PKA, PKC, and MAPK transduction pathways and can be accounted for by inhibition of oxidative stress-induced mitochondrial dysfunctions and caspase activation.

Keywords: hemoglobin, oxidative stress, astrocytes, apoptosis, cell protection

\section{INTRODUCTION}

Hemoglobin $(\mathrm{Hb})$ is a heme protein mainly present in erythrocytes of vertebrates $(1,2)$. Hb is known to function as a carrier protein of oxygen $\left(\mathrm{O}_{2}\right)$ and carbon monoxide $(\mathrm{CO})$, and thus ensures transport of $\mathrm{O}_{2}$ to the tissues, cell oxygen-consuming, and catalysis of redox reactions (3-6).

Abbreviations: $\mathrm{Hb}$, hemoglobin; $\mathrm{H}_{2} \mathrm{O}_{2}$, hydrogen peroxide; MAPK, mitogen-activated protein kinase; NO, nitric oxide; PKA, protein kinase A; PKC, protein kinase $\mathrm{C}$; ROS, reactive oxygen species. 
It was traditionally thought that release of $\mathrm{Hb}$ from erythrocytes was deleterious for the brain during intracerebral hemorrhage and trauma $(2,7,8)$ and that free $\mathrm{Hb}$ induced a strong oxidative stress and inflammation, which were responsible for neuronal apoptosis (9-12). However, increasing evidences suggest that neurotoxicity associated to $\mathrm{Hb}$ derives from erythrocyte breakdown and may be accounted for iron accumulation in tissue neighboring hematomas $(9,13)$, rather than an accumulation of $\mathrm{Hb}$ molecule by itself $(8,14)$. In fact, iron chelators provide neuroprotection in intracerebral hemorrhage $(15,16)$, or in cultured astrocytes or neurons incubated with higher doses of $\mathrm{Hb}$ $(9,17,18)$. Moreover, it has been reported that low doses of $\mathrm{Hb}$ maintain nitric oxide (NO) homeostasis and act as scavenger of reactive oxygen species (ROS) such as hydrogen peroxide $\left(\mathrm{H}_{2} \mathrm{O}_{2}\right)$ (19-22) to protect cells from oxidative damages. Indeed, it has been reported that $\mathrm{Hb}$ prevents death of presenilin-1-deficient neurons induced by oxidative stress (23). In addition, overexpression of $\mathrm{Hb}$ has been found to be protective in rat models of ischemia and thereby increases neuron survival in hypoxic conditions (24). Altogether, these observations suggest that endogenous $\mathrm{Hb}$ could exert a strong protective effect and attenuate cellular ROS accumulation.

There is now clear evidence that $\mathrm{Hb}$ is expressed not only in erythroid cells but also in other cell types including neurons and glia cells $(6,25,26)$. The occurrence of $\mathrm{Hb}$-like immunoreactivity and $\mathrm{Hb}$ mRNA has been visualized in different regions of the brain, notably in the cortex, hippocampus, and cerebellum (13, 25-27). In particular, it has been shown that $\mathrm{Hb}$ transcript and protein levels are increased in cortical neurons and astroglial cells during the preconditioning phase of ischemia both in vivo and in vitro $(28,29)$. On the other hand, high concentrations of $\mathrm{Hb}$ mRNA and protein are found in human gliomas (30), indicating that over expression of $\mathrm{Hb}$ may have a role in promoting cell proliferation. An age-related decline in $\mathrm{Hb}$ expression in astrocytes has been found, suggesting that loss of this protein may increase susceptibility to age-related neurological disorders (31). Moreover, it has been indicated that induction of glia $\mathrm{Hb}$ expression contributes to reduce neuronal cell death under hypoxia conditions (24). Altogether, these results suggest that upregulation of astrocytic $\mathrm{Hb}$ may play a critical role in the pathogenesis of brain disorders; however, the function of endogenous astroglial $\mathrm{Hb}$, which is present in much lower concentrations than found in blood, in astrocyte proliferation and/or survival is still not clear.

Since astrocytes play prominent role in the protection of neurons against oxidative injury, loss of astroglial cells may critically impair neuronal survival $(32,33)$. Thus, protection of astrocytes from oxidative insult appears essential to maintain brain function. Although there is clear evidence that Hb expression is upregulated in astroglial cells after traumatic brain injury and stroke $(24,29)$ and could exert neuroprotective activity $(23,30)$, a possible effect of $\mathrm{Hb}$ on astrocyte survival has never been investigated.

The purpose of the present study was thus to examine the potential protective action of $\mathrm{Hb}$ against $\mathrm{H}_{2} \mathrm{O}_{2}$-induced astroglial cell death and to investigate some of the mechanisms involved in this effect.

\section{ANIMALS AND METHODS}

\section{Animals}

Wistar rats (Pasteur Institute, Tunis) were kept in a temperaturecontrolled room $\left(21 \pm 1^{\circ} \mathrm{C}\right)$, under an established photoperiod (lights on 0700-1900 hours) and with free access to food and water.

\section{Reagents}

Dulbecco's modified Eagle's medium (DMEM), Ham F12 culture medium, $\mathrm{D}(+)$-glucose, $\mathrm{L}$-glutamine, $\mathrm{N}$-2-hydroxyethylpiperazine$\mathrm{N}$-2-ethane sulfonic acid (HEPES), fetal bovine serum (FBS), and the antibiotic-antimycotic solution, were obtained from Life Technologies (Grand Island, NY, USA). H89, chelerythrine, fluorescein diacetate-acetoxymethyl (FDA-AM), dimethyl sulfoxide (DMSO), insulin, Triton X-100, and bovine $\mathrm{Hb}$ were purchased from Sigma-Aldrich (St. Louis, MO, USA). The lactate dehydrogenase (LDH; EC 1.1.1.27) assay kit was obtained from Bio-Maghreb (Tunis, Tunisia). 5-6-chloromethyl 2'-7'dichlorodihydrofluorescein diacetate (CM- $\left.\mathrm{H}_{2} \mathrm{DCFDA}\right), \mathrm{JC}-10$, and 4,5-diamino fluorescein diacetate (DAF-FM) were from Molecular Probes (Eugene, OR, USA). U0126 and Apo-ONE Homogeneous Caspase-3/7 assay kit were supplied by Promega (Charbonnières, France).

\section{Cell Culture}

Secondary cultures of rat cortical astrocytes were prepared from 1- or 2-day-old Wistar rats of both sexes as previously described (34). Briefly, cerebral hemispheres were dissected, meninges removed, and tissues collected in DMEM/Ham F12 (2:1; v/v) culture medium supplemented with $2 \mathrm{mM}$ glutamine, $1 \%$ insulin, $5 \mathrm{mM}$ HEPES, $0.4 \%$ glucose (final concentration of glucose in culture media is $4.5 \mathrm{~g} / \mathrm{L}$ ), and $1 \%$ of the antibiotic-antimycotic solution. The tissues were dissociated mechanically with a syringe equipped with a $25 \mathrm{G}$ gage needle, and filtered through a $100-\mu \mathrm{m}$ sieve (Falcon, Franklin Lakes, NJ, USA). Dissociated cells were resuspended in culture medium supplemented with 10\% FBS, plated in $75-\mathrm{cm}^{2}$ flasks (Greiner Bio-one $\mathrm{GmbH}$, Frickenhausen, Germany) at the density of $17 \times 10^{6}$ cells $/ \mathrm{mL}$ and incubated at $37^{\circ} \mathrm{C}$ in $5 \% \mathrm{CO}_{2} / 95 \%$ air. After $7-8$ days, the cultures became confluent and loosely attached microglia cells and oligodendrocytes were removed by shaking the flasks on an orbital agitator (250 rpm, $18 \mathrm{~h}$ ). Adhesive cells (mostly astrocytes) were detached by trypsinization, harvested and plated on 24- or 96-well plates at a density of $8 \times 10^{4}$ cells $/ \mathrm{mL}$. All experiments were performed on 5 - to 7 -day-old secondary cultures and more than $98 \%$ of the cells were labeled with antibodies against glial fibrillary acidic protein (35).

\section{Experimental Design}

All experiments were performed on DIV 5-7 astroglial cells grown up in culture medium containing $10 \%$ of FBS. After removal of medium, cells were incubated at $37^{\circ} \mathrm{C}$ with fresh serum-free culture medium in the absence or presence of the test substances for $24 \mathrm{~h}$. Previous data indicated that incubation of astrocytes during $24 \mathrm{~h}$ with $50 \mu \mathrm{M} \mathrm{H}_{2} \mathrm{O}_{2}$ induces about $40 \%$ of cell death (36). Thus, a dose of $50 \mu \mathrm{M} \mathrm{H}_{2} \mathrm{O}_{2}$ was used in the present study to evaluate the effect of $\mathrm{Hb}$ on astrocyte survival. On the basis of the 
results shown in Figures 1, 2 and 3A, a concentration of $10^{-9} \mathrm{M}$ $\mathrm{Hb}$, which prevents the deleterious effects of $\mathrm{H}_{2} \mathrm{O}_{2}$, was used in all subsequent experiments. It has been previously demonstrated that $2 \times 10^{-5} \mathrm{M} \mathrm{H} 89,10^{-6} \mathrm{M}$ chelerythrine, and $10^{-6} \mathrm{M} \mathrm{U} 0126$ blocked the protective effects of some neuropeptides on cultured astrocytes $(35,37)$. Thus these concentrations were also used in the present study.

\section{Measurement of Cell Survival}

At the end of the treatment period, cells were washed twice with phosphate-buffered saline (PBS, 0.1 M, pH 7.4) and incubated for $8 \mathrm{~min}$ with $15 \mu \mathrm{g} / \mathrm{mL}$ FDA-AM in the dark, rinsed twice with PBS, and lysed with a Tris/ $\mathrm{HCl}$ solution containing $1 \%$ sodium dodecyl sulfate. Fluorescence was measured with excitation at $485 \mathrm{~nm}$ and emission at $538 \mathrm{~nm}$ using a fluorescence microplate reader FL800TBI (Bio-Tek Instruments, Winooski, VT, USA). Experiments were carried out on 16 different wells from four independent experiments.

\section{Measurement of Intracellular ROS Formation}

ROS were detected by measuring the fluorescence of $2^{\prime}, 7^{\prime}$-dichlorofluorescein (DCF), which is derived from the deacetylation and oxidation of the non-fluorescent compound $\mathrm{DCFH}_{2}-\mathrm{DA}$. At the end of the treatment period, cells were washed twice with $\mathrm{PBS}$, and then incubated with $10 \mu \mathrm{M} \mathrm{DCFH}_{2}-\mathrm{DA}$ for $30 \mathrm{~min}$ at $37^{\circ} \mathrm{C}$ in the dark. Fluorescence was measured with excitation at $485 \mathrm{~nm}$ and emission at $538 \mathrm{~nm}$ using a fluorescence microplate reader. Experiments were carried on 18 different wells from three independent experiments.

\section{Measurement of NO Accumulation}

Relative changes in cytosolic NO concentration in astrocytes were monitored using the fluorescent probe 4,5-diamino fluorescein diacetate (DAF). At the end of the treatment period, cells were washed twice with PBS and then incubated with $10 \mu \mathrm{M}$ DAF-FM diacetate for $30 \mathrm{~min}$. Fluorescence was measured with excitation at $485 \mathrm{~nm}$ and emission at $538 \mathrm{~nm}$ using a fluorescence microplate reader. Experiments were carried out on 18 different wells from three independent experiments.

\section{Measurement of Mitochondrial Activity}

Mitochondrial membrane potential was quantified using the JC-10 probe. Cells seeded into 96-well plates were incubated in the absence or presence of $\mathrm{H}_{2} \mathrm{O}_{2}$ with or without $\mathrm{Hb}$. At the end of the treatment, astrocytes were incubated in the presence of the JC-10 probe $(10 \mu \mathrm{g} / \mathrm{mL})$ at $37^{\circ} \mathrm{C}$ for $1 \mathrm{~h}$, and then washed twice with PBS. In healthy astrocytes, the intact membrane potential allows the lipophilic dye JC-10 to enter into the mitochondria where it aggregates and produces an intense orange signal. In dead cells, mitochondrial membrane potential collapses so that the monomeric JC-10 probe remains cytosolic and emits a green signal. Fluorescence intensity was measured with fluorescence microplate reader and expressed as a ratio of the emission at $610 \mathrm{~nm}$ (orange) over $530 \mathrm{~nm}$ (green) to evaluate mitochondrial integrity (38). Experiments were carried out on 12 different wells from three independent experiments.

\section{Measurement of Caspase 3 Activity}

The effect of $\mathrm{Hb}$ on $\mathrm{H}_{2} \mathrm{O}_{2}$-induced increase of caspase 3 activity was measured by using Apo-ONE Homogeneous Caspase-3/7 kit (Promega). At the end of the incubation, $100 \mu \mathrm{L}$ of the cell suspension was incubated with $100 \mu \mathrm{L}$ of kit buffer and caspase substrat. Caspase- 3 activity was calculated from the slope of the fluorescence measured every $15 \mathrm{~min}$ for $3 \mathrm{~h}$ with excitation at $485 \mathrm{~nm}$ and emission at $530 \mathrm{~nm}$. Experiments were carried out on 12 different wells from three independent experiments.

\section{Cell Cytotoxicity Measurement}

The cytotoxicity of $\mathrm{H}_{2} \mathrm{O}_{2}$ on astrocytes was determined by measuring the activity of $\mathrm{LDH}$ released into the culture medium, using a LDH assay kit (Bio-Maghreb, Tunis, Tunisia) according to the manufacturer's instructions. LDH activity was measured at $340 \mathrm{~nm}$ with a spectrophotometric microplate reader. The results were expressed as a percentage of total LDH release after cell lysis with $1 \%$ Triton X-100 in PBS. Experiments were carried out on 16 different wells from four independent experiments.

\section{Statistical Analysis}

The data were presented as mean \pm SEM of at least three independent experiments $(n \geq 3)$. The statistical analysis of the data was performed using Student's $t$-test for single comparisons and by ANOVA followed by Bonferroni's test, and two-way ANOVA test for multiple comparisons with the GraphPad software ( $\mathrm{La}$ Jolla, CA, USA). In all cases a $p$-value of 0.05 or less was considered as statistically significant.

\section{RESULTS}

\section{Protective Effect of $\mathrm{Hb}$ against $\mathrm{H}_{2} \mathrm{O}_{2}$ - Induced Astroglial Cell Death}

Incubation of cultured astrocytes with $50 \mu \mathrm{M} \mathrm{H} \mathrm{H}_{2} \mathrm{O}_{2}$ for $24 \mathrm{~h}$ induced a decrease $(-37.2 \pm 1.9 \% ; p<0.001)$ of the proportion of surviving cells. Administration of graded concentrations of $\mathrm{Hb}$ $\left(10^{-12}\right.$ to $\left.10^{-6} \mathrm{M}\right)$, which did not affect cell viability by themselves, dose-dependently prevented cell death induced by $50 \mu \mathrm{M} \mathrm{H}_{2} \mathrm{O}_{2}$ (Figure 1A). Examination of cultures by phase-contrast microscopy revealed that $\mathrm{H}_{2} \mathrm{O}_{2}$ induced cell shrinkage and disturbance of the astrocyte network with appearance of retracted processes (Figure 1B, b). The effect of $\mathrm{H}_{2} \mathrm{O}_{2}$ on morphological alterations was slightly attenuated with low concentration $\left(10^{-12} \mathrm{M}\right)$ of $\mathrm{Hb}$ (Figure 1B, c) and totally prevented with higher concentrations of $\mathrm{Hb}$, condition in which cells exhibited a flat polygonal morphology similar to that of untreated-astrocytes (Figure 1B, a,d).

\section{Effect of $\mathrm{Hb}$ on $\mathrm{H}_{2} \mathrm{O}_{2}$-Induced Intracellular ROS and NO Accumulation in Cultured Astrocytes}

To examine whether $\mathrm{Hb}$ could block $\mathrm{H}_{2} \mathrm{O}_{2}$-induced intracellular ROS accumulation, astrocytes were labeled with $\mathrm{CMH}_{2} \mathrm{DCFDA}$, 


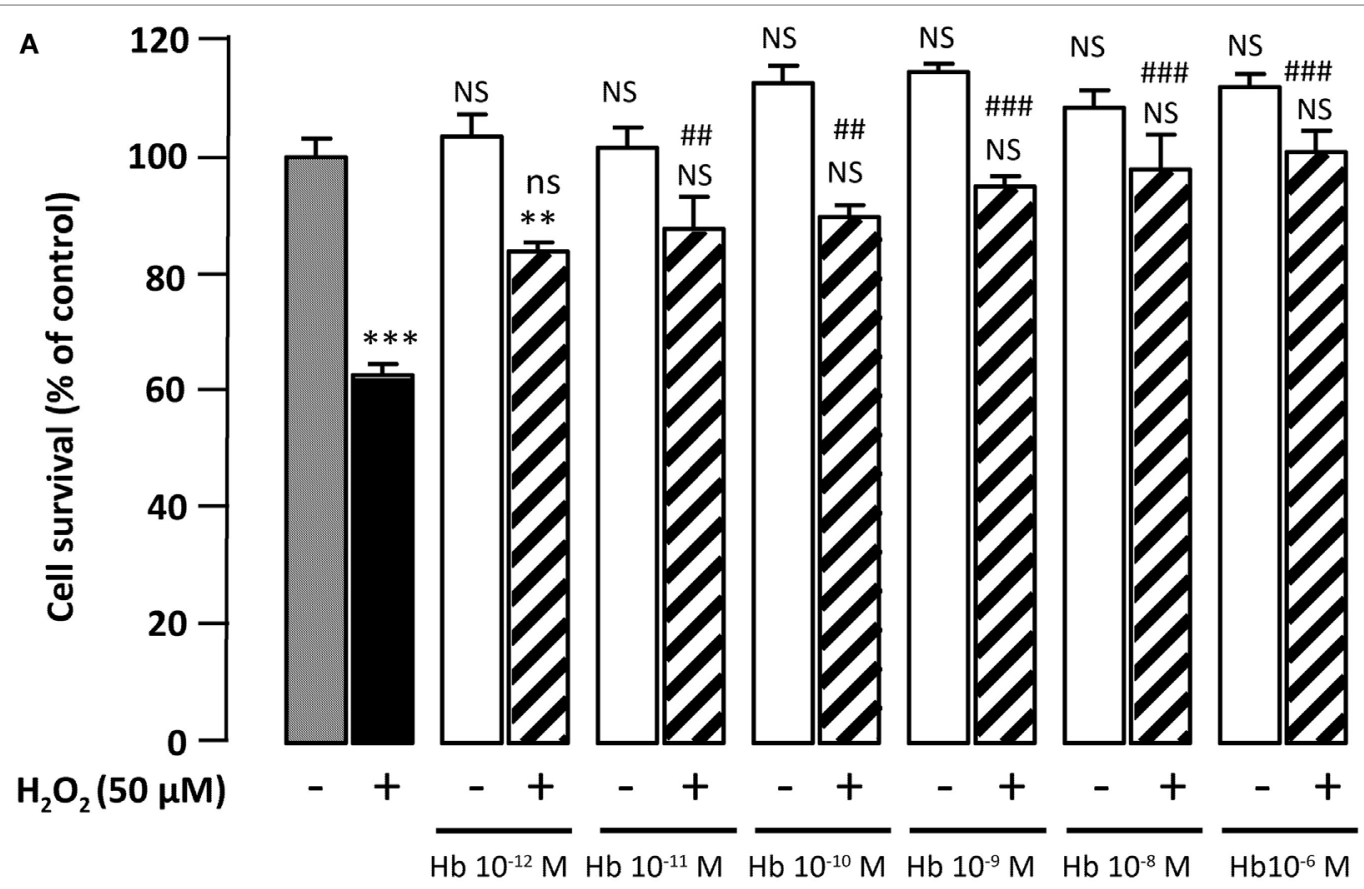

B
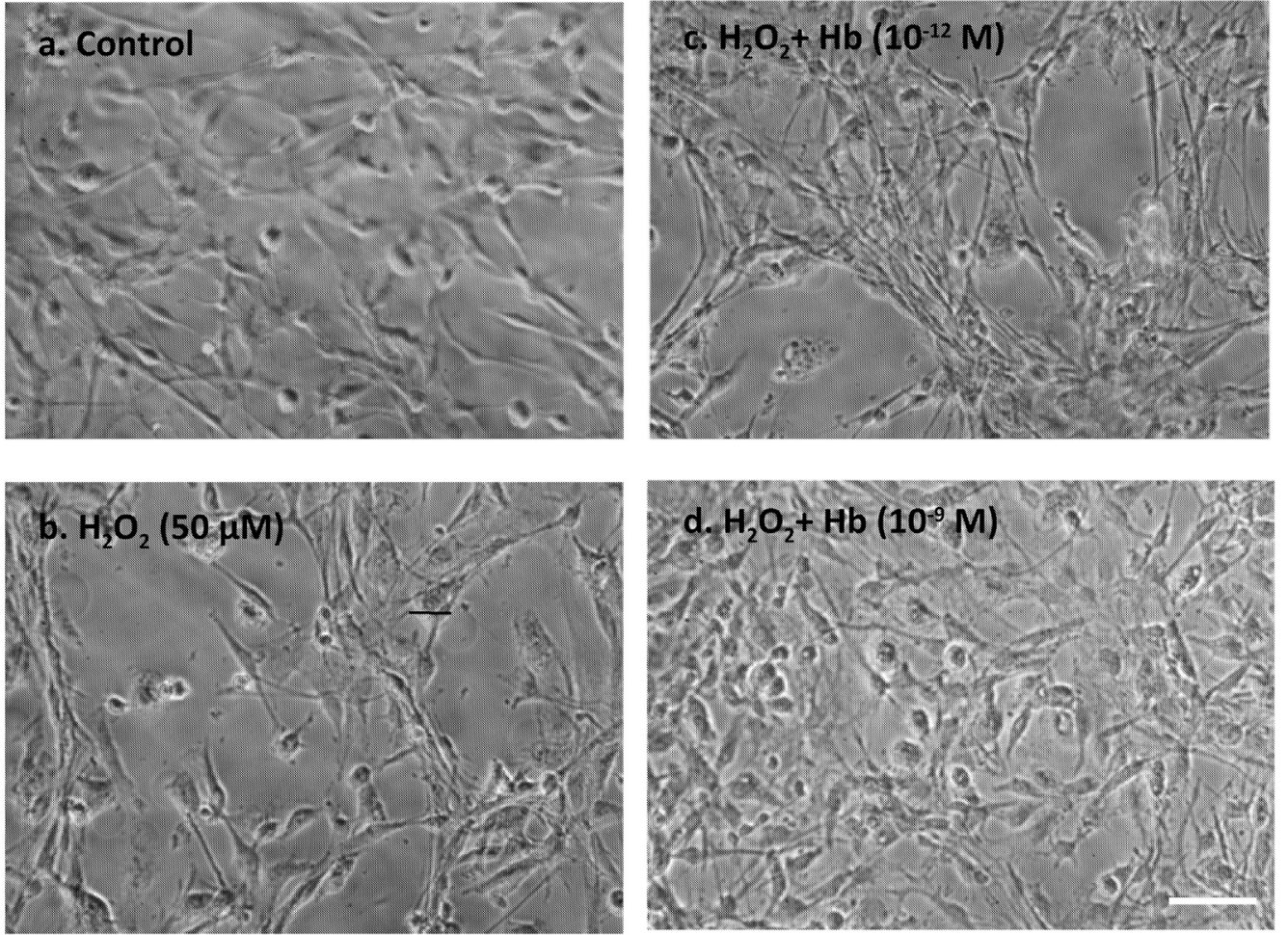

FIGURE 1 Glioprotective effect of $\mathbf{H b}$ on $\mathrm{H}_{2} \mathrm{O}_{2}$-induced cell death. (A) Cells were co-incubated for $24 \mathrm{~h}$ with medium alone $\left(\square\right.$ or with $\mathrm{H}_{2} \mathrm{O}_{2}(50 \mu \mathrm{M})$ in the absence $\square$ or presence of graded concentration of $\mathrm{Hb}\left(10^{-12}\right.$ to $\left.10^{-6} \mathrm{M}, \boldsymbol{Z}\right)$. Cell survival was quantified by measuring FDA fluorescence intensity, and the results are expressed as percentages of the control. Data are means \pm SEM of four independent experiments. ANOVA followed by Bonferroni's test ${ }^{\star \star *} p<0.001 ;$ NS, not statistically different from control cells (absence of $\mathrm{H}_{2} \mathrm{O}_{2}$ and absence of $\mathrm{Hb}$ ). ${ }^{\# \#} p<0.01$; \#\#\# $p<0.001$; ns, not statistically different vs. $\mathrm{H}_{2} \mathrm{O}_{2}$-treated cells. (B) Typical phase-contrast images illustrating the effect of $\mathrm{Hb}$ on $\mathrm{H}_{2} \mathrm{O}_{2}$-induced morphological changes in cultured rat astrocytes. Cells were incubated for $24 \mathrm{~h}$ with medium alone (a), or $50 \mu \mathrm{M} \mathrm{H}_{2} \mathrm{O}_{2}$ in the absence (b), or presence of $10^{-12} \mathrm{M} \mathrm{Hb}$ (c), or $10^{-9} \mathrm{M} \mathrm{Hb}$ (d). Scale bar $100 \mu \mathrm{m}$. 
A

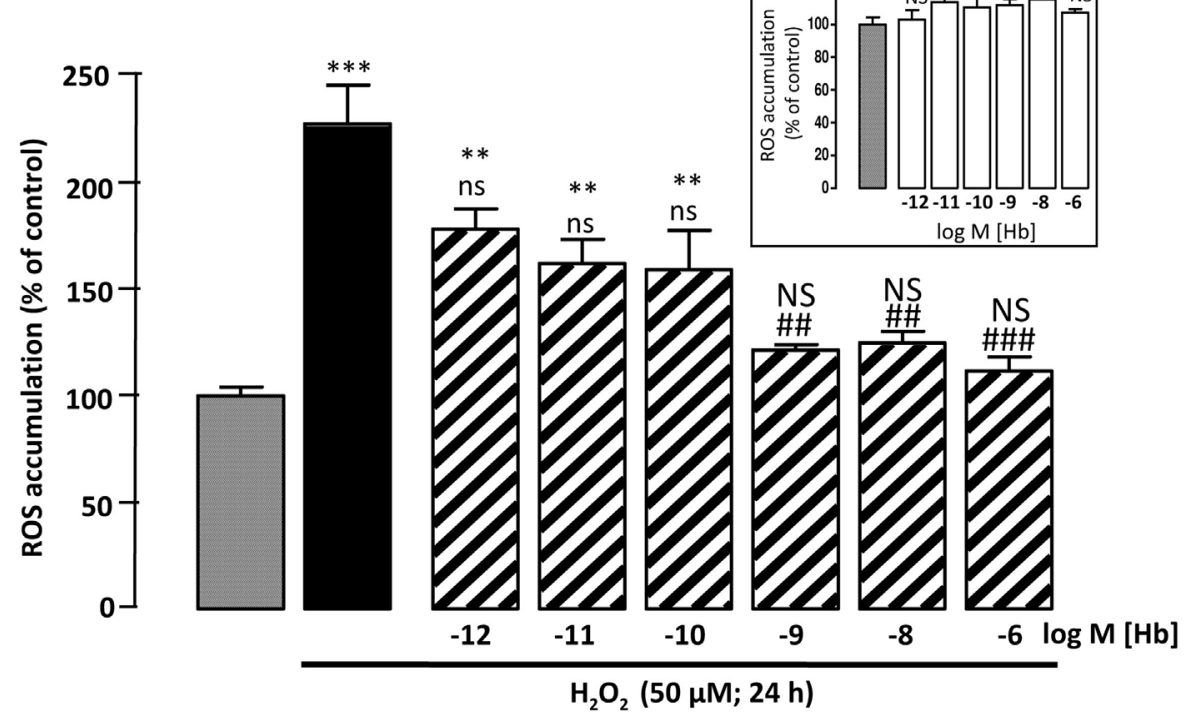

B
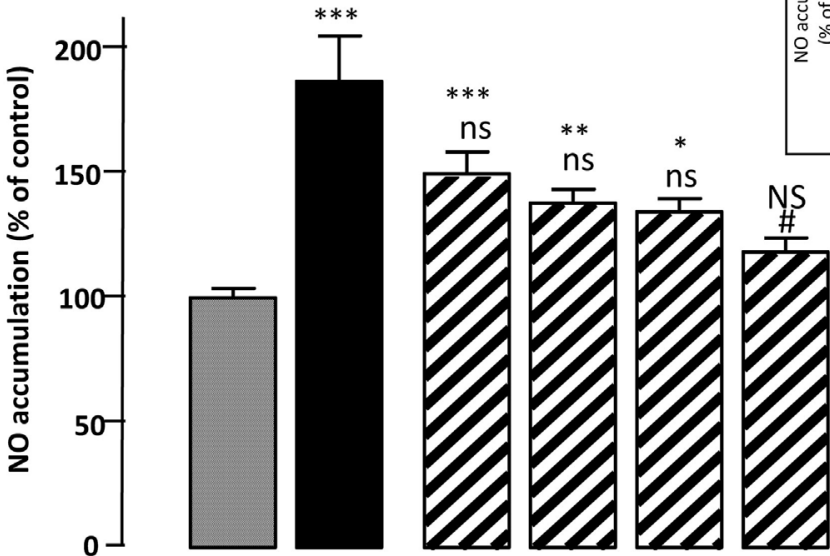

$-12 \quad-11$

$\mathrm{H}_{2} \mathrm{O}_{2}(50 \mu \mathrm{M} ; 24 \mathrm{~h})$
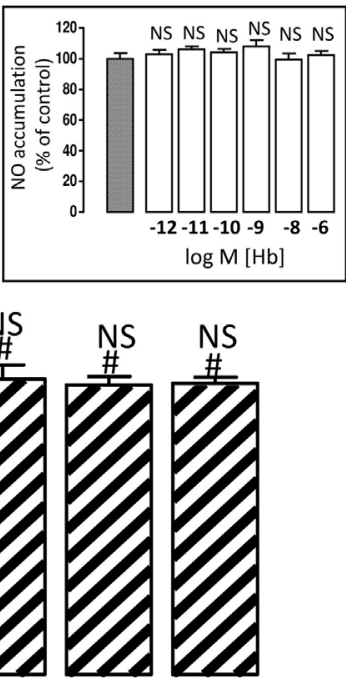

$-8$

$-6 \log \mathrm{M}[\mathrm{Hb}]$

FIGURE 2 | Effect of $\mathrm{Hb}$ on $\mathrm{H}_{2} \mathrm{O}_{2}$-induced ROS and NO intracellular accumulations. Cells were co-incubated for $24 \mathrm{~h}$ with medium alone $\left(\square\right.$ or with $\mathrm{H}_{2} \mathrm{O}_{2}$ $(50 \mu \mathrm{M})$ in the absence $(\boldsymbol{\square})$ or presence of graded concentration of $\mathrm{Hb}\left(10^{-12}\right.$ to $10^{-6} \mathrm{M}$, $\left.\mathbf{Z}\right)$. (A) Cellular ROS level was quantified by measurement of DCF fluorescence intensity. (B) Cellular NO level was quantified by measurement of DAF fluorescence intensity. Inset, effect of graded concentration of $\mathrm{Hb}\left(10^{-12}\right.$ to $10^{-6} \mathrm{M} ; \square$ ) on intracellular ROS accumulation (A) and NO formation (B). The results are expressed as percentages of the controls. Data are means \pm SEM of three independent experiments. ANOVA followed by Bonferroni's test ${ }^{*} p<0.05$; ${ }^{* *} p<0.01 ;{ }^{* \star *} p<0.001$; NS, not statistically different from control cells. ${ }^{\#} p<0.05$; ${ }^{\# \#} p<0.01 ; \# \#<0.001$; ns, not statistically different vs. $\mathrm{H}_{2} \mathrm{O}_{2}$-treated cells.

which forms the fluorescent DCF compound by oxidation with ROS. Incubation of cultured astrocytes with $50 \mu \mathrm{M} \mathrm{H}_{2} \mathrm{O}_{2}$ alone for $24 \mathrm{~h}$, induced an increase in DCF fluorescence intensity $(+127 \pm 18 \% ; p<0.001)$. Incubation of cells with graded concentrations of $\mathrm{Hb}\left(10^{-12}\right.$ to $\left.10^{-6} \mathrm{M}\right)$ had no effect on DCF fluorescence intensity (Inset), but reduced in a dose-dependent manner, the effect of $\mathrm{H}_{2} \mathrm{O}_{2}$ on DCF formation (Figure 2A). Since large amounts of NO are produced by cells under oxidative stress status (39), we have investigated the effect of $\mathrm{Hb}$ on $\mathrm{H}_{2} \mathrm{O}_{2}$-induced $\mathrm{NO}$ formation in astroglial cells. By using the DAF-FM probe, which forms the fluorescent DAF compound upon oxidation by $\mathrm{NO}$, we found that $\mathrm{H}_{2} \mathrm{O}_{2}$ induced a significant increase $(+86.6 \pm 18.23 \% ; p<0.001)$ of $\mathrm{NO}$ production and, in the same range of concentrations, $\mathrm{Hb}$ was also able to reduce in a dose-dependent manner the effect of $50 \mu \mathrm{M}$ $\mathrm{H}_{2} \mathrm{O}_{2}$ on DAF formation (Figure 2B). In contrast, all concentrations of $\mathrm{Hb}$ tested did not affect, by themselves, $\mathrm{NO}$ production (inset). 

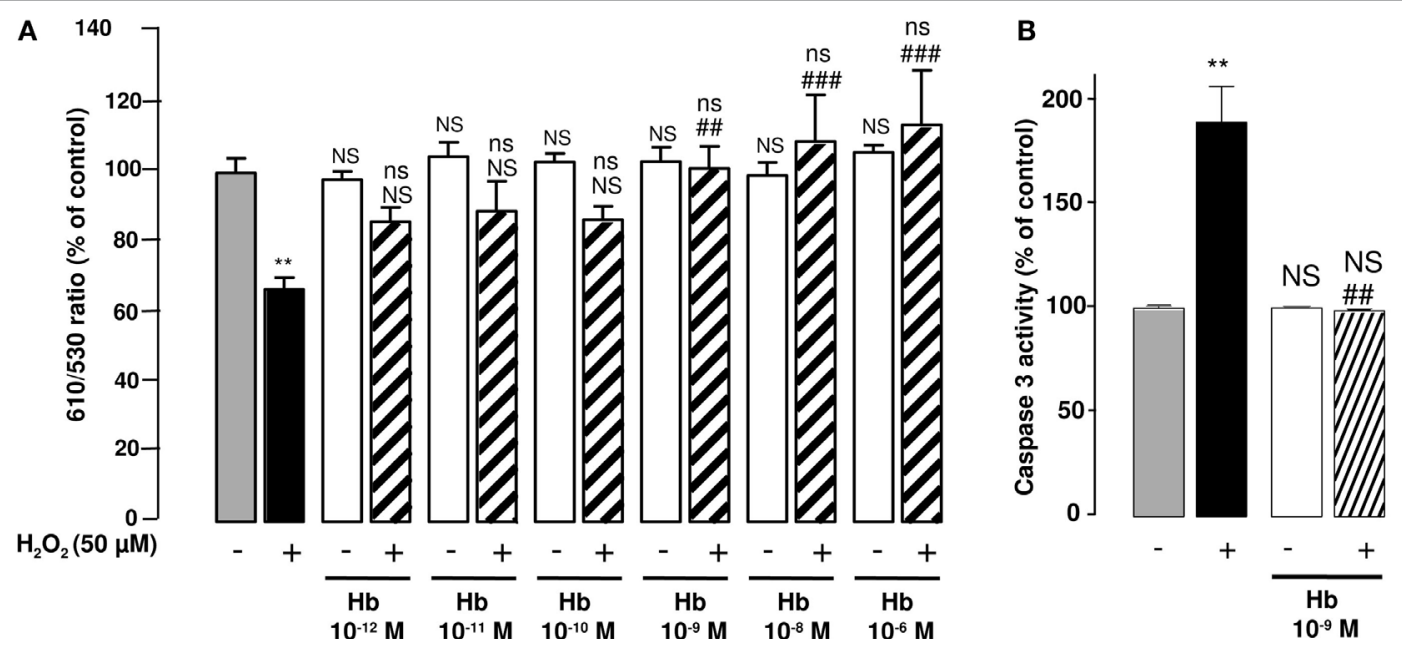

FIGURE 3 | Effect of $\mathrm{Hb}$ on $\mathrm{H}_{2} \mathrm{O}_{2}$-induced alteration of mitochondrial membrane potential and caspase-3 activation in cultured astrocytes. Cells were co-incubated for $24 \mathrm{~h}$ with medium alone $\square$ or with $\mathrm{H}_{2} \mathrm{O}_{2}(50 \mu \mathrm{M})$ in the absence $(\square)$ or presence of graded concentrations of $\mathrm{Hb}^{\left(10^{-12}\right.}$ to $10^{-6} \mathrm{M}$, $\left.\boldsymbol{Z}\right)$. (A) Mitochondrial transmembrane potential was assessed by using the $\mathrm{JC}-10$ probe, and the ratio of fluorescence emissions $610 / 530 \mathrm{~nm}$ was measured as an index of mitochondrial activity. (B) Caspase 3 activity was measured by caspase substrate, Z-DEVDRhodamine 110, fluorescence. The results are expressed as percentage of controls. Data are means \pm SEM of three independent experiments. ANOVA followed by Bonferroni's test. ${ }^{* \star} p<0.01$; ns, not statistically different from control cells. ${ }^{\#} p<0.01$; ${ }^{\# \#} p<0.001$; ns, not statistically different vs. $\mathrm{H}_{2} \mathrm{O}_{2}$-treated cells.

\section{Effect of $\mathrm{Hb}$ on $\mathrm{H}_{2} \mathrm{O}_{2}$-Induced Mitochondrial Potential Alteration and Caspase-3 Activation}

Considering the major action of oxidative stress in the alteration of mitochondria functions, we have examined the effect of $\mathrm{Hb}$ on the integrity of mitochondria by using the fluorescent ratiometric probe JC-10. Treatment of astrocytes with $50 \mu \mathrm{M} \mathrm{H}_{2} \mathrm{O}_{2}$ alone induced a significant reduction $(-32.6 \pm 3.4 \% ; p<0.01)$ of the $610 / 530 \mathrm{~nm}$ ratio, indicating that the mitochondrial integrity was impaired by oxidative stress. Incubation of cells with graded concentrations of $\mathrm{Hb}\left(10^{-12}\right.$ to $\left.10^{-6} \mathrm{M}\right)$ did not affect $610 / 530 \mathrm{~nm}$ fluorescence ratio, but dose-dependently reduced the deleterious effect of $\mathrm{H}_{2} \mathrm{O}_{2}$ on the mitochondrial membrane potential, and the $610 / 530 \mathrm{~nm}$ ratio was restored to control values for concentrations greater than $10^{-9} \mathrm{M}$ (Figure 3A). $\mathrm{H}_{2} \mathrm{O}_{2}$-induced reduction of membrane potential was associated with an increase of caspase 3 activity $(+89.3 \pm 17.19 \%$; $p<0.05)$. Addition of $\mathrm{Hb}\left(10^{-9} \mathrm{M}\right)$ in the incubation medium totally suppressed the stimulatory effect of $\mathrm{H}_{2} \mathrm{O}_{2}$ on caspase 3 activation (Figure 3B).

\section{Identification of the Signal Transduction Pathways Involved in the Glioprotective Effect of $\mathrm{Hb}$ on $\mathrm{H}_{2} \mathrm{O}_{2}$-Induced Astroglial Death}

Incubation of astrocytes with $50 \mu \mathrm{M} \mathrm{H}_{2} \mathrm{O}_{2}$ for $24 \mathrm{~h}$ induced an increase of $\mathrm{LDH}$ levels in the culture medium $(+82.6 \pm 7.55 \%$; $p<0.01$ ) (Figure 4A). Addition of $\mathrm{Hb}$ at the dose of $10^{-9} \mathrm{M}$ to the culture medium abolished the effect of $\mathrm{H}_{2} \mathrm{O}_{2}$ on LDH leakage $(100.2 \pm 0.9 \%)$ (Figure $4 \mathrm{~A})$. To investigate the signaling cascade involved in the protective action of $\mathrm{Hb}$, we have used pharmacological inhibitors of adenylyl cyclase (AC)/protein kinase A (PKA), phospholipase C (PLC)/protein kinase C $(\mathrm{PKC})$, or mitogen-activated protein kinase (MAPK) transduction pathways. Incubation of astrocytes with the PKA inhibitor H89 $\left(2 \times 10^{-5} \mathrm{M}\right)$, the PKC inhibitor chelerythrine $\left(10^{-6} \mathrm{M}\right)$ or the mitogen-activated protein kinase kinase (MEK) inhibitor U0126 $\left(10^{-6} \mathrm{M}\right)$, which had no effect by themself on cell damage and cell death induced by $\mathrm{H}_{2} \mathrm{O}_{2}$, abrogated the protective action of $\mathrm{Hb}\left(10^{-9} \mathrm{M}\right)$ on $\mathrm{H}_{2} \mathrm{O}_{2}$-provoked toxicity and cell death (Figures 4A,B).

\section{DISCUSSION}

The main finding of the present study is to demonstrate for the first time that $\mathrm{Hb}$ protects astroglial cells against oxidative stress and death induced by $\mathrm{H}_{2} \mathrm{O}_{2}$ exposure. It has been found that $\mathrm{Hb}$ is effective at very low concentrations and exerts its glioprotective effect through inhibition of ROS and NO generation, mitochondrial dysfunctions, and caspase- 3 activation.

In agreement with previous reports $(35,40,41)$, we observed that $\mathrm{H}_{2} \mathrm{O}_{2}$-treated astrocytes exhibited modifications of cell morphology such as cell shrinkage and appearance of thin processes. In parallel, $\mathrm{H}_{2} \mathrm{O}_{2}$ induced an increase of $\mathrm{LDH}$ in the medium and a decrease of cell survival. Here, we showed that $\mathrm{Hb}$ dose-dependently prevented $\mathrm{H}_{2} \mathrm{O}_{2}$-induced cell death and abolished $\mathrm{H}_{2} \mathrm{O}_{2}$-evoked morphological changes. These data could be seemed in contradiction with previous studies indicating that $\mathrm{Hb}$ released from red blood cells in intracerebral hemorrhage is neurotoxic (9, 30, 42-44). Nevertheless, it can be noted that the concentration of $\mathrm{Hb}$ detected in this pathology is 10,000 times higher than that used in the present study. In addition, the concentration of $\mathrm{Hb}$ needed to prevent 

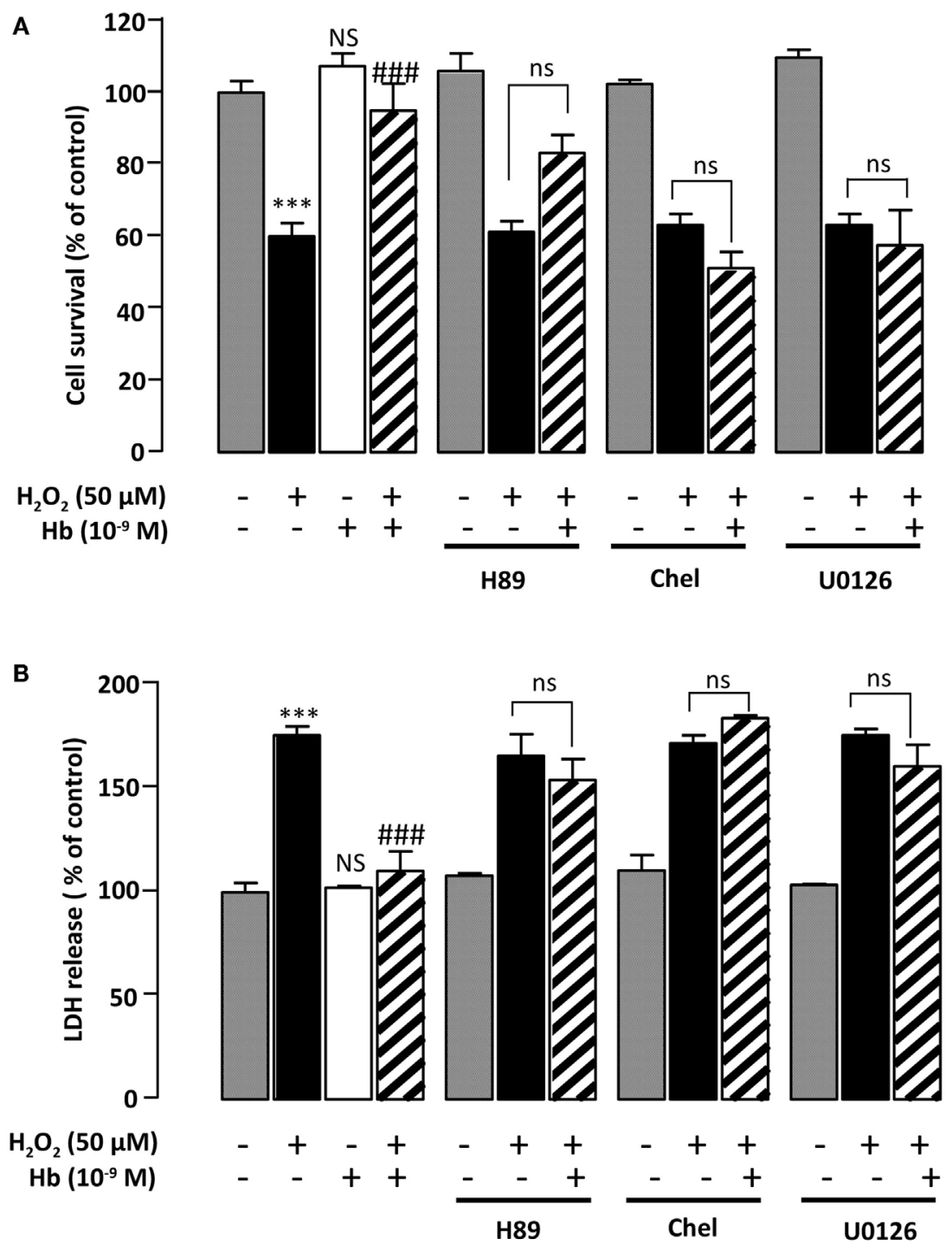

FIGURE 4 | Characterization of intracellular pathways involved in the protective effect of Hb on astroglial cells. Cells were pre-incubated for 30 min in the absence or presence of $\mathrm{H} 89\left(2 \times 10^{-5} \mathrm{M}\right)$, chelerythrine $\left(10^{-6} \mathrm{M}\right.$; Chel), or U0126 $\left(10^{-6} \mathrm{M}\right)$ and then incubated for $24 \mathrm{~h}$ with medium alone $(\square) \mathrm{Hb}\left(10^{-9} \mathrm{M}\right)$ alone or with $\mathrm{H}_{2} \mathrm{O}_{2}(50 \mu \mathrm{M})$ in the absence $(\mathbf{\square})$ or presence of $\mathrm{Hb}(\mathbf{Z})$. (A) Cell death was determined by measuring LDH activity in culture media, and the results are expressed as percentage of LDH released in Triton-lysed cells. (B) Cell survival was quantified by measuring FDA fluorescence intensity, and the results are expressed as percentages of control. Data are means \pm SEM of four independent experiments. ANOVA followed by Bonferroni's test ${ }^{* \star *} p<0.001 ;$ NS, not statistically different from control cells. ${ }^{\# \# \# ~}<0.001$; ns, not statistically different vs. $\mathrm{H}_{2} \mathrm{O}_{2}$-treated cells.

the deleterious effects of $\mathrm{H}_{2} \mathrm{O}_{2}$ on astroglial cells (the present data) was in the same range as that produced by neuronal cells brain, i.e., cortical and hippocampal neurons and astrocytes $(25,45,46)$. Furthermore, there is now mounting evidence indicating that endogenous neuronal $\mathrm{Hb}$ is not detrimental in brain diseases (30) and even may exert beneficial effects on neuronal cells in in vivo and in vitro models of ischemia $(24,45)$. While, the precise roles of $\mathrm{Hb}$ in brain physiology and in neurodegenerative diseases are not well understood. Since, astrocytes produce neuroprotective compounds, that $\mathrm{Hb}$ protects glial cells against moderate injuries could be benefit for brain neuronal populations. As in the case of $\mathrm{Hb}$, the potency and efficacy of others oxygen-binding globins, neuroglobin, and myogolobin, in preventing neuronal cell death have been proven against various neurotoxins, including $\mathrm{H}_{2} \mathrm{O}_{2}$, and brain injuries induced by hypoxia, ischemia, or stroke $(30,47-51)$. It is noteworthy that subnanomolar concentrations of $\mathrm{Hb}$ were still effective to protect astrocytes from the cytotoxic effect of $\mathrm{H}_{2} \mathrm{O}_{2}$ after $24 \mathrm{~h}$ of treatment, indicating that this globin exhibits a strong cytoprotective activity.

It is well documented in numerous cell types including astrocytes that $\mathrm{H}_{2} \mathrm{O}_{2}$ exerts its cytotoxic effect via the production of highly reactive species inside the cell $(34,51-53)$. The present study reveals that treatment of astrocytes with $\mathrm{Hb}$ reduced, in a concentration-dependent manner, intracellular ROS and NO levels, phenomenum, which is likely responsible for a reduction 
of cell death induced by $\mathrm{H}_{2} \mathrm{O}_{2}$. In agreement with the fact that $\mathrm{Hb}$ may protect astrocytes from oxidative stress, it has been demonstrated that (i) $\mathrm{Hb}$ strongly scavengers ROS and $\mathrm{NO}$ (6), (ii) $\mathrm{Hb}$ overexpression prevents $\mathrm{H}_{2} \mathrm{O}_{2}$-induced ROS surproduction and cell death in primary rat mesangial cells (54), and (iii) increasing expression of neuronal $\mathrm{Hb}$ prior to hypoxia insult enhances neuronal cell viability by decreasing oxidative stress process $(45$, $55)$. It cannot be excluded that peroxidase activity of $\mathrm{Hb}(56,57)$ could be in part responsive for its protective effect against $\mathrm{H}_{2} \mathrm{O}_{2}$.

It is widely accepted that ROS can induce cell death by multiple intracellular mechanisms including mitochondrial dysfunction leading to the formation of mitochondrial permeability transition pores and thus activation of caspases, the effectors of apoptotic cell death $(37,58,59)$. In agreement with this notion, measurement of mitochondria activity, with the membrane potential-sensitive probe JC-10, revealed that treatment of astrocytes with $\mathrm{H}_{2} \mathrm{O}_{2}$ resulted in a decrease of the proportion of active mitochondria, and that co-administration of nanomolar concentration of $\mathrm{Hb}$ prevented the deleterious effect of $\mathrm{H}_{2} \mathrm{O}_{2}$ on mitochondria. Concurrently, $\mathrm{Hb}$ suppressed stimulation of caspase-3/7 activity induced by $\mathrm{H}_{2} \mathrm{O}_{2}$. That $\mathrm{Hb}$ exerts its glioprotective effect through the intrinsic mitochondrial pathway is supported by a study showing that Hb blocks the effects of NO on (i) the decrease of procaspase- 2 protein levels, an inactive form of caspase-2, (ii) the stimulation of caspase- 3 activity, (iii) the cleavage of poly (ADP-ribose) polymerase (PARP) and the DNA fragmentation, and (iv) the apoptotic cell death in human neuroblastoma SH-SY5Y cells $(60,61)$. In addition, $\mathrm{Hb}$ reverses heme oxygenase-1/CO-provoked neuronal cell death through inhibition of caspase-3-dependent apoptotic pathway (62). Thus, collectively, these data strongly suggest that $\mathrm{Hb}$ rescues astrocytes from oxidative stress by preventing ROS accumulation, which in turn preserves mitochondrial activity and prevents caspase- 3 activation. In support of this hypothesis, it has been shown that the globin neuroglobin, the neuropeptides octadecaneuropeptide, and pituitary adenylate cyclase-activating polypeptide, which can rescue astrocytes from oxidative damages, inhibit the effects of $\mathrm{H}_{2} \mathrm{O}_{2}$ on alteration of mitochondrial integrity and stimulation of caspase $3 / 7$ activity $(35,37,51,63)$.

That $\mathrm{Hb}$, by itself, might peroxidate $\mathrm{H}_{2} \mathrm{O}_{2}$ in culture media, and that this effect might be responsible for the protective effect of $\mathrm{Hb}$, cannot be totally excluded. Nevertheless, in the present study, the protective effect of $\mathrm{Hb}$ was shown at very low doses $\left(10^{-11}\right.$ to $\left.10^{-6} \mathrm{M}\right)$ and peroxidation of $\mathrm{H}_{2} \mathrm{O}_{2}$ by $\mathrm{Hb}$ has been found at doses 1,000- to 10,000 times higher than that used in the present study $(56,57)$. In addition, the peroxidase activity of $\mathrm{Hb}$ is optimal at $\mathrm{pH} 5.5$, and dramatically falls down at physiological $\mathrm{pH}$ (57).

Although our understanding of the precise signaling pathways that trigger apoptosis of neuronal cells is still fragmentary, it has been demonstrated that activation of the AC/PKA and the PLC/PKC transduction pathways contributes to reduce intracellular ROS levels and to protect cells against oxidative stress-induced apoptosis in cultured neurons and astrocytes $(34,64,65)$. Here, we show that treatment of astrocytes with the PKA inhibitor $\mathrm{H} 89$ or the PKC inhibitor chelerythrine abrogated the effects of $\mathrm{Hb}$ on $\mathrm{H}_{2} \mathrm{O}_{2}$-evoked caspase-3/7 activation and cell death apoptosis. We have previously demonstrated that the MAPK signaling cascade is involved in apoptotic death of astrocytes $(37,51)$, and it has been shown that survival of astrocytes requires phosphorylation of extracellular signalregulated kinase (43). Consistently, we show that the protective action of $\mathrm{Hb}$ on astrocytes against $\mathrm{H}_{2} \mathrm{O}_{2}$ was abolished by the MEK inhibitor U0126. Collectively, these data suggest that the glioprotective activity of $\mathrm{Hb}$ can be accounted for by activation of the PKA, PKC, and MAPK transduction pathways. The receptor through which $\mathrm{Hb}$ might modulate intracellular pathways in astrocytes and exert its glioprotective effect is currently unknown. Alternatively, it can be proposed that $\mathrm{Hb}$, in the same way as neuroglobin, could directly interact with $G$ proteins and thus modulates transduction pathways (66-68). However, such hypothesis raises the question how $\mathrm{Hb}$ crosses the membrane. The delivery of $\mathrm{Hb}$ inside astrocytes might result to its interaction with the scavenger receptor CD163, which acts as a $\mathrm{Hb}$ transporter in macrophages (69). That CD163, or other receptor or mechanism, might be involved in the uptake of $\mathrm{Hb}$ by astrocytes merits further investigations.

The protective effect of low doses of $\mathrm{Hb}$ on astroglial cells might have a physiopathological significance in neurological disorders including neurodegenerative diseases, like ischemia and stroke. Clinical studies have shown that the neuronal $\mathrm{Hb}$ expression is reduced in brain of patient with Alzheimer disease, Parkinson disease, or dementia with Lewy Bodies (27). Along these lines, it has been reported that treatment of rat with rotenone, neurotoxin used to reproduce features of Parkinson's disease (70), induces downregulation of $\mathrm{Hb}$ expression in selected neuronal populations, i.e., nigral, cortical, and striatal neurons, associated with an elevation of oxidative stress damages and mitochondria dysfunction $(55,71)$. In contrast, upregulation of neuronal expression of $\mathrm{Hb}$ is accompanied by enhanced resistance to oxidative stress under hypoxic conditions (45). Despite their high antioxidative activities, astroglial cells cannot survive and protect neurons under insurmountable oxidative stress (32). Thus, upregulation of $\mathrm{Hb}$ expression in astrocytes might increase protection of cells from oxidative insults and might delay neuronal damages in various cerebral injuries involving oxidative neurodegeneration.

In conclusion, the present study demonstrates that $\mathrm{Hb}$ at low concentrations acts as endogenous protective agent against oxidative and nitrosative stress inducing apoptosis of cultured astrocytes. The antiapoptotic effect of this globin is attributable, at least in part, to the reduction of ROS formation, which preserves mitochondrial functions and prevents caspase 3 activation.

\section{ETHICS STATEMENT}

Approval for these experiments was obtained from the Medical Ethical Committee for the Care and Use of Laboratory Animals of Pasteur Institute of Tunis (approval number: FST/LNFP/ Pro152-012). 


\section{AUTHOR CONTRIBUTIONS}

FA, MA, and OM-K conceived and designed the experiments. FA, IG, and OM-K performed the experiments. FA, M-CT, MA, and OM-K analyzed the data. FA, IG, M-CT, MA, and OM-K contributed to reagents/materials/analysis tools. FA, M-CT, and $\mathrm{OM}-\mathrm{K}$ wrote the paper.

\section{ACKNOWLEDGMENTS}

FA and IG were recipients of fellowships from the University of Tunis El Manar, a France-Tunisia exchange program and FranceTunisia exchange programs PHC-Utique.

\section{REFERENCES}

1. Edsall JT. Understanding blood and hemoglobin: an example of international relations in science. Perspect Biol Med (1986) 29:S107-23. doi:10.1353/pbm.1986.0052

2. Zhou Y, Wang Y, Wang J, Anne Stetler R, Yang QW. Inflammation in intracerebral hemorrhage: from mechanisms to clinical translation. Prog Neurobiol (2014) 115:25-44. doi:10.1016/j.pneurobio.2013.11.003

3. Rahaman MM, Straub AC. The emerging roles of somatic globins in cardiovascular redox biology and beyond. Redox Biol (2013) 1:405-10. doi:10.1016/j. redox.2013.08.001

4. Burmester T. Evolution of respiratory proteins across the pancrustacea. Integr Comp Biol (2015) 55:792-801. doi:10.1093/icb/icv079

5. Cook SA, Hill EA, Borovik AS. Lessons from nature: a bio-inspired approach to molecular design. Biochemistry (2015) 54:4167-80. doi:10.1021/acs. biochem.5b00249

6. Quaye IK. Extracellular hemoglobin: the case of a friend turned foe. Front Physiol (2015) 6:96. doi:10.3389/fphys.2015.00096

7. Laird MD, Wakade C, Alleyne CH Jr, Dhandapani KM. Hemin-induced necroptosis involves glutathione depletion in mouse astrocytes. Free Radic Biol Med (2008) 45:1103-14. doi:10.1016/j.freeradbiomed.2008.07.003

8. Jaremko KM, Chen-Roetling J, Chen L, Regan RF. Accelerated hemolysis and neurotoxicity in neuron-glia-blood clot co-cultures. J Neurochem (2010) 114:1063-73. doi:10.1111/j.1471-4159.2010.06826.x

9. Vanderveldt GM, Regan RF. The neurotoxic effect of sickle cell hemoglobin. Free Radic Res (2004) 38:431-7. doi:10.1080/10715760310001638010

10. Lara FA, Kahn SA, da Fonseca AC, Bahia CP, Pinho JP, Graca-Souza AV, et al. On the fate of extracellular hemoglobin and heme in brain. J Cereb Blood Flow Metab (2009) 29:1109-20. doi:10.1038/jcbfm.2009.34

11. Sukumari-Ramesh S, Laird MD, Singh N, Vender JR, Alleyne CH Jr, Dhandapani KM. Astrocyte-derived glutathione attenuates hemin-induced apoptosis in cerebral microvascular cells. Glia (2010) 58:1858-70. doi:10.1002/glia.21055

12. Wang YC, Zhou Y, Fang H, Lin S, Wang PF, Xiong RP, et al. Toll-like receptor $2 / 4$ heterodimer mediates inflammatory injury in intracerebral hemorrhage. Ann Neurol (2014) 75:876-89. doi:10.1002/ana.24159

13. Bishop GM, Robinson SR. Quantitative analysis of cell death and ferritin expression in response to cortical iron: implications for hypoxia-ischemia and stroke. Brain Res (2001) 907:175-87. doi:10.1016/S0006-8993(01)02303-4

14. Bamm VV, Lanthier DK, Stephenson EL, Smith GS, Harauz G. In vitro study of the direct effect of extracellular hemoglobin on myelin components. Biochim Biophys Acta (2015) 1852:92-103. doi:10.1016/j.bbadis.2014.10.009

15. Huang FP, Xi G, Keep RF, Hua Y, Nemoianu A, Hoff JT. Brain edema after experimental intracerebral hemorrhage: role of hemoglobin degradation products. J Neurosurg (2002) 96:287-93. doi:10.3171/jns.2002.96.2.0287

16. RighyC,BozzaMT,OliveiraMF,BozzaFA.Molecular,cellularandclinicalaspects of intracerebral hemorrhage: are the enemies within? Curr Neuropharmacol (2016) 14:392-402. doi:10.2174/1570159X14666151230110058

17. Regan RF, Rogers B. Delayed treatment of hemoglobin neurotoxicity. J Neurotrauma (2003) 20:111-20. doi:10.1089/08977150360517236

18. Owen JE, Bishop GM, Robinson SR. Phenanthrolines protect astrocytes from hemin without chelating iron. Neurochem Res (2014) 39:693-9. doi:10.1007/ s11064-014-1256-8

\section{FUNDING}

This study was supported by the Laboratory of Functional Neurophysiology and Pathology (UR/11ES09) and alternance scholarship of Tunisian Higher Education Ministry, a FranceTunisia exchange program CMCU-Campus France PHC Utique grant number 16G0820/34940PK (to OM-K and David Vaudry), France-Tunisia exchange program CMCU-Utique (grant number 13G0815), a France-Tunisia exchange program No. SSHN2016, and the Institute for Medical Research and Innovation (IRIB). The funders had no role in study design, data collection and analysis, decision to publish, or preparation of the manuscript.

19. Masuoka N, Kodama H, Abe T, Wang DH, Nakano T. Characterization of hydrogen peroxide removal reaction by hemoglobin in the presence of reduced pyridine nucleotides. Biochim Biophys Acta (2003) 1637:46-54. doi:10.1016/ S0925-4439(02)00213-2

20. Goldstein S, Samuni A. Intra- and intermolecular oxidation of oxymyoglobin and oxyhemoglobin induced by hydroxyl and carbonate radicals. Free Radic Biol Med (2005) 39:511-9. doi:10.1016/j.freeradbiomed.2005.04.003

21. Chen K, Piknova B, Pittman RN, Schechter AN, Popel AS. Nitric oxide from nitrite reduction by hemoglobin in the plasma and erythrocytes. Nitric Oxide (2008) 18:47-60. doi:10.1016/j.niox.2007.09.088

22. Schechter AN. Hemoglobin research and the origins of molecular medicine. Blood (2008) 112:3927-38. doi:10.1182/blood-2008-04-078188

23. Nakajima M, Shirasawa T. Presenilin-1-deficient neurons are nitric oxide-dependently killed by hydrogen peroxide in vitro. Neuroscience (2004) 125:563-8. doi:10.1016/j.neuroscience.2004.01.016

24. Tezel G, Yang X, Luo C, Cai J, Kain AD, Powell DW, et al. Hemoglobin expression and regulation in glaucoma: insights into retinal ganglion cell oxygenation. Invest Ophthalmol Vis Sci (2010) 51:907-19. doi:10.1167/iovs.09-4014

25. Biagioli M, Pinto M, Cesselli D, Zaninello M, Lazarevic D, Roncaglia P, et al. Unexpected expression of alpha- and beta-globin in mesencephalic dopaminergic neurons and glial cells. Proc Natl Acad Sci U S A (2009) 106:15454-9. doi:10.1073/pnas.0813216106

26. Chuang JY, Lee CW, Shih YH, Yang T, Yu L, Kuo YM. Interactions between amyloid-beta and hemoglobin: implications for amyloid plaque formation in Alzheimer's disease. PLoS One (2012) 7:e33120. doi:10.1371/journal. pone. 0033120

27. Ferrer I, Gomez A, Carmona M, Huesa G, Porta S, Riera-Codina M, et al. Neuronal hemoglobin is reduced in Alzheimer's disease, argyrophilic grain disease, Parkinson's disease, and dementia with Lewy bodies. J Alzheimers Dis (2011) 23:537-50. doi:10.3233/JAD-2010-101485

28. He Y, Hua Y, Liu W, Hu H, Keep RF, Xi G. Effects of cerebral ischemia on neuronal hemoglobin. J Cereb Blood Flow Metab (2009) 29:596-605. doi:10.1038/ jcbfm.2008.145

29. He Y, Hua Y, Keep RF, Liu W, Wang MM, Xi G. Hemoglobin expression in neurons and glia after intracerebral hemorrhage. Acta Neurochir Suppl (2011) 111:133-7. doi:10.1007/978-3-7091-0693-8_22

30. Xie LK, Yang SH. Brain globins in physiology and pathology. Med Gas Res (2016) 6:154-63. doi:10.4103/2045-9912.191361

31. Orre M, Kamphuis W, Osborn LM, Melief J, Kooijman L, Huitinga I, et al. Acute isolation and transcriptome characterization of cortical astrocytes and microglia from young and aged mice. Neurobiol Aging (2014) 35:1-14. doi:10.1016/j.neurobiolaging.2013.07.008

32. Belanger M, Magistretti PJ. The role of astroglia in neuroprotection. Dialogues Clin Neurosci (2009) 11:281-95.

33. L' Episcopo F, Tirolo C, Testa N, Caniglia S, Morale MC, Marchetti B. Glia as a turning point in the therapeutic strategy of Parkinson's disease. CNS Neurol Disord Drug Targets (2010) 9:349-72. doi:10.2174/187152710791292639

34. Masmoudi-Kouki O, Douiri S, Hamdi Y, Kaddour H, Bahdoudi S, Vaudry D, et al. Pituitary adenylate cyclase-activating polypeptide protects astroglial cells against oxidative stress-induced apoptosis. J Neurochem (2011) 117:403-11. doi:10.1111/j.1471-4159.2011.07185.x 
35. Douiri S, Bahdoudi S, Hamdi Y, Cubi R, Basille M, Fournier A, et al. Involvement of endogenous antioxidant systems in the protective activity of pituitary adenylate cyclase-activating polypeptide against hydrogen peroxide-induced oxidative damages in cultured rat astrocytes. J Neurochem (2016) 137:913-30. doi:10.1111/jnc.13614

36. Moriyama M, Jayakumar AR, Tong XY, Norenberg MD. Role of mitogen-activated protein kinases in the mechanism of oxidant-induced cell swelling in cultured astrocytes. J Neurosci Res (2010) 88:2450-8. doi:10.1002/jnr.22400

37. Hamdi Y, Kaddour H, Vaudry D, Bahdoudi S, Douiri S, Leprince J, et al. The octadecaneuropeptide ODN protects astrocytes against hydrogen peroxide-induced apoptosis via a PKA/MAPK-dependent mechanism. PLoS One (2012) 7:e42498. doi:10.1371/journal.pone.0042498

38. Liu YY, Sparatore A, Del Soldato P, Bian JS. H2S releasing aspirin protects amyloid beta induced cell toxicity in BV-2 microglial cells. Neuroscience (2011) 193: 80-8. doi:10.1016/j.neuroscience.2011.07.023

39. Quincozes-Santos A, Bobermin LD, Latini A, Wajner M, Souza DO, Goncalves CA, et al. Resveratrol protects C6 astrocyte cell line against hydrogen peroxide-induced oxidative stress through heme oxygenase 1. PLoS One (2013) 8:e64372. doi:10.1371/journal.pone.0064372

40. Ferrero-Gutierrez A, Perez-Gomez A, Novelli A, Fernandez-Sanchez MT. Inhibition of protein phosphatases impairs the ability of astrocytes to detoxify hydrogen peroxide. Free Radic Biol Med (2008) 44:1806-16. doi:10.1016/j. freeradbiomed.2008.01.029

41. Hamdi Y, Masmoudi-Kouki O, Kaddour H, Belhadj F, Gandolfo P, Vaudry D, et al. Protective effect of the octadecaneuropeptide on hydrogen peroxide-induced oxidative stress and cell death in cultured rat astrocytes. J Neurochem (2011) 118:416-28. doi:10.1111/j.1471-4159.2011.07315.x

42. Regan RF, Guo Y, Kumar N. Heme oxygenase-1 induction protects murine cortical astrocytes from hemoglobin toxicity. Neurosci Lett (2000) 282:1-4. doi:10.1016/S0304-3940(00)00817-X

43. Rollins S, Perkins E, Mandybur G, Zhang JH. Oxyhemoglobin produces necrosis, not apoptosis, in astrocytes. Brain Res (2002) 945:41-9. doi:10.1016/ S0006-8993(02)02562-3

44. Tejima E, Zhao BQ, Tsuji K, Rosell A, van Leyen K, Gonzalez RG, et al. Astrocytic induction of matrix metalloproteinase- 9 and edema in brain hemorrhage. J Cereb Blood Flow Metab (2007) 27:460-8. doi:10.1038/sj.jcbfm.9600354

45. Schelshorn DW, Schneider A, Kuschinsky W, Weber D, Kruger C, Dittgen T, et al. Expression of hemoglobin in rodent neurons. J Cereb Blood Flow Metab (2009) 29:585-95. doi:10.1038/jcbfm.2008.152

46. Russo R, Zucchelli S, Codrich M, Marcuzzi F, Verde C, Gustincich S. Hemoglobin is present as a canonical $\alpha 2 \beta 2$ tetramer in dopaminergic neurons. Biochim Biophys Acta (2013) 1834:1939-43. doi:10.1016/j.bbapap.2013.05.005

47. Li RC, Morris MW, Lee SK, Pouranfar F, Wang Y, Gozal D. Neuroglobin protects PC12 cells against oxidative stress. Brain Res (2008) 1190:159-66. doi:10.1016/j.brainres.2007.11.022

48. Li RC, Guo SZ, Lee SK, Gozal D. Neuroglobin protects neurons against oxidative stress in global ischemia. J Cereb Blood Flow Metab (2010) 30:1874-82. doi:10.1038/jcbfm.2010.90

49. Watanabe S, Takahashi N, Uchida H, Wakasugi K. Human neuroglobin functions as an oxidative stress-responsive sensor for neuroprotection. J Biol Chem (2012) 287:30128-38. doi:10.1074/jbc.M112.373381

50. Qiu XY, Chen XQ. Neuroglobin - recent developments. Biomol Concepts (2014) 5:195-208. doi:10.1515/bmc-2014-0011

51. Amri F, Ghouili I, Amri M, Carrier A, Masmoudi-Kouki O. Neuroglobin protects astroglial cells from hydrogen peroxide-induced oxidative stress and apoptotic cell death. J Neurochem (2017) 140:151-69. doi:10.1111/jnc.13876

52. Le HT, Sin WC, Lozinsky S, Bechberger J, Vega JL, Guo XQ, et al. Gap junction intercellular communication mediated by connexin 43 in astrocytes is essential for their resistance to oxidative stress. J Biol Chem (2014) 289:1345-54. doi:10.1074/jbc.M113.508390

53. Ramalingam M, Kim SJ. Insulin on hydrogen peroxide-induced oxidative stress involves ROS/Ca2+ and Akt/Bcl-2 signaling pathways. Free Radic Res (2014) 48:347-56. doi:10.3109/10715762.2013.869588

54. Nishi H, Inagi R, Kato H, Tanemoto M, Kojima I, Son D, et al. Hemoglobin is expressed by mesangial cells and reduces oxidant stress. J Am Soc Nephrol (2008) 19:1500-8. doi:10.1681/ASN.2007101085

55. Saha D, Patgaonkar M, Shroff A, Ayyar K, Bashir T, Reddy KV. Hemoglobin expression in nonerythroid non-erythroid cells: novel or ubiquitous? Int J Inflam (2014) 2014:803237. doi:10.1155/2014/803237
56. Kapralov A, Vlasova II, Feng W, Maeda A, Walson K, Tyurin VA, et al. Peroxidase activity of hemoglobin-haptoglobin complexes: covalent aggregation and oxidative stress in plasma and macrophages. J Biol Chem (2009) 284:30395-407. doi:10.1074/jbc.M109.045567

57. Grigorieva DV, Gorudko IV, Sokolov AV, Kosmachevskaya OV, Topunov AF, Buko IV, et al. Measurement of plasma hemoglobin peroxidase activity. Bull Exp Biol Med (2013) 155:118-21. doi:10.1007/s10517-013-2094-4

58. Wang JY, Shum AY, Ho YJ, Wang JY. Oxidative neurotoxicity in rat cerebral cortex neurons: synergistic effects of $\mathrm{H}_{2} \mathrm{O}_{2}$ and $\mathrm{NO}$ on apoptosis involving activation of p38 mitogen-activated protein kinase and caspase-3. J Neurosci Res (2003) 72:508-19. doi:10.1002/jnr.10597

59. Sastre J, Serviddio G, Pereda J, Minana JB, Arduini A, Vendemiale G, et al. Mitochondrial function in liver disease. Front Biosci (2007) 12:1200-9. doi: $10.2741 / 2138$

60. Uehara T, Nomura Y. [Possible involvement of caspase activation in nitric oxide-induced neuronal apoptosis in SH-SY5Y cells]. Nihon Yakurigaku Zasshi (1998) 112(Suppl 1):118-22. doi:10.1254/fpj.112.supplement_118

61. Uehara T, Kikuchi Y, Nomura Y. Caspase activation accompanying cytochrome $\mathrm{c}$ release from mitochondria is possibly involved in nitric oxide-induced neuronal apoptosis in SH-SY5Y cells. J Neurochem (1999) 72:196-205. doi:10.1046/j.1471-4159.1999.0720196.x

62. Yang CM, Hsieh HL, Lin CC, Shih RH, Chi PL, Cheng SE, et al. Multiple factors from bradykinin-challenged astrocytes contribute to the neuronal apoptosis: involvement of astroglial ROS, MMP-9, and HO-1/CO system. Mol Neurobiol (2013) 47:1020-33. doi:10.1007/s12035-013-8402-1

63. Hamdi Y, Kaddour H, Vaudry D, Douiri S, Bahdoudi S, Leprince J, et al. The stimulatory effect of the octadecaneuropeptide ODN on astroglial antioxidant enzyme systems is mediated through a GPCR. Front Endocrinol (2012) 3:138. doi:10.3389/fendo.2012.00138

64. Seaborn T, Masmoudi-Kouki O, Fournier A, Vaudry H, Vaudry D. Protective effects of pituitary adenylate cyclase-activating polypeptide (PACAP) against apoptosis. Curr Pharm Des (2011) 17:204-14. doi:10.2174/ 138161211795049679

65. Kaddour H, Hamdi Y, Vaudry D, Basille M, Desrues L, Leprince J, et al. The octadecaneuropeptide ODN prevents 6-hydroxydopamine-induced apoptosis of cerebellar granule neurons through a PKC-MAPK-dependent pathway. J Neurochem (2013) 125:620-33. doi:10.1111/jnc.12140

66. Takahashi N, Watanabe S, Wakasugi K. Crucial roles of Glu60 in human neuroglobin as a guanine nucleotide dissociation inhibitor and neuroprotective agent. PLoS One (2013) 8:e83698. doi:10.1371/journal.pone.0083698

67. Guidolin D, Agnati LF, Tortorella C, Marcoli M, Maura G, Albertin G, et al. Neuroglobin as a regulator of mitochondrial-dependent apoptosis: a bioinformatics analysis. Int J Mol Med (2014) 33:111-6. doi:10.3892/ijmm. 2013.1564

68. Takahashi N, Wakasugi K. Identification of residues crucial for the interaction between human neuroglobin and the alpha-subunit of heterotrimeric Gi protein. Sci Rep (2016) 6:24948. doi:10.1038/srep24948

69. Schaer CA, Schoedon G, Imhof A, Kurrer MO, Schaer DJ. Constitutive endocytosis of CD163 mediates hemoglobin-heme uptake and determines the noninflammatory and protective transcriptional response of macrophages to hemoglobin. Circ Res (2006) 99: 943-50. doi:10.1161/01. RES.0000247067.34173.1b

70. Sherer TB, Betarbet R, Testa CM, Seo BB, Richardson JR, Kim JH, et al. Mechanism of toxicity in rotenone models of Parkinson's disease. J Neurosci (2003) 23:10756-64.

71. Richter F, Meurers BH, Zhu C, Medvedeva VP, Chesselet MF. Neurons express hemoglobin alpha- and beta-chains in rat and human brains. J Comp Neurol (2009) 515:538-47. doi:10.1002/cne.22062

Conflict of Interest Statement: The authors declare that the research was conducted in the absence of any commercial or financial relationships that could be construed as a potential conflict of interest.

Copyright (c) 2017 Amri, Ghouili, Tonon, Amri and Masmoudi-Kouki. This is an open-access article distributed under the terms of the Creative Commons Attribution License (CC BY). The use, distribution or reproduction in other forums is permitted, provided the original author(s) or licensor are credited and that the original publication in this journal is cited, in accordance with accepted academic practice. No use, distribution or reproduction is permitted which does not comply with these terms. 